\title{
RESEARCH IMPACT ASSESSMENT: FROM EX POST TO REAL-TIME ASSESSMENT
}

\author{
PIERRE-BENOIT JOLY, MIREILLE MATT AND DOUGLAS K. R. ROBINSON \\ DOI: $10.22163 /$ fteval.2019.326
}

\section{INTRODUCTION}

$\mathrm{T}$ This paper presents an ongoing research and development project to build research management tools based on real-time impact analysis (the toolset is labelled ASIRPArt). The ambition is to use the lessons learned from ex post research impact assessment (RIA), building from the ASIRPA project which was launched in 2011 (Joly et al. 2015, Matt et al. 2017). The ASIRPA approach is currently implemented on a routine base at the French public research organisation INRA (Institut National de la Recherche Agronomique). Therefore, the project draws on lessons learned from ex post RIA and the experience of researchers and actors involved in research programming.

The aim of ASIRPA ${ }^{\text {rt }}$ is to design an approach and tools to help conduct research projects or programmes with the aim to amplify impacts. The challenge of the current project is to develop management tools based on a better understanding of the mechanisms that generate research impact. These tools will be coproduced with potential users (Robinson and Rip 2013).

Given the uncertainty and complexity that characterise the transformation processes linked to research activities, we do not intend to design ballistic steering tools but to produce tools to foster learning processes, coordination and reflexivity of the actors involved. Our approach takes inspiration in different streams of literature.

First, based on Kuhlman (2003), we consider that such tools should foster competences of the actors involved in research activities and research programming, as well as strengthen collective learning and coordination. Second, our general representation of transformation processes linked to research activities is inspired by innovation studies, and more precisely actor-network theory (Callon 1986) and the innovation journey (Van de Ven et al. 1999). According to these theoretical frames, the processes involved cannot be steered and planned because they generate new knowledge, new socio-technical associations and their effect depends on the progressive alignments of many heterogeneous elements. To paraphrase Van de Ven (2016), one cannot control such complex and uncertain processes, but one can still learn to manoeuvre it.

With such tools and the interactions that it can generate, we also aim at favouring exchanges between users and thus contributing to the creation of communities of practice that will themselves contribute to improving the approach.

\section{STATE OF THE ART, CONCEPTS AND APPROACHES}

Since the beginning of the 2010's, RIA benefits from a renewed interest (Joly and Matt 2017). Although the field is still moving quickly, we know a lot on ex post RIA and relatively little on in itinere or ex ante assessment. In our project, we use the expression 'real time' to signify that what matters is the design of tools for continoues assessment of the transformative capacity of research and learning how to 'manoeuvre' for enhancing impact. Such tools take inspiration of ex post analysis and aim to enhance skills of actors involved for ex ante or in itinere conduct of research activities. Our idea is that these tools have to be designed to serve at different scales, from the project level to the programme level or any relevant cluster of projects. The landscape of RIA proposed by LERU in the context of the preparation of FPg is relevant to our approach (Figure 1).

\begin{tabular}{|c|c|c|c|c|c|}
\hline \multirow{2}{*}{$\begin{array}{c}\text { Impact } \\
\text { assessment } \\
\text { and } \\
\text { enhancement }\end{array}$} & \multirow[b]{2}{*}{ Ex-ante } & \multirow[b]{2}{*}{ During } & \multicolumn{3}{|c|}{ Ex-post } \\
\hline & & & $\begin{array}{l}\text { short-term } \\
\text { (end of project }+1 \text { year) }\end{array}$ & $\begin{array}{l}\text { medium-term } \\
(+1-7 \text { years })\end{array}$ & $\begin{array}{l}\text { Long-term } \\
(+7-15 \text { years })\end{array}$ \\
\hline \multirow[t]{2}{*}{ Call and project level } & \multirow{2}{*}{$\begin{array}{l}\text { Pathways to impact } \\
\text { statement }\end{array}$} & \multicolumn{3}{|c|}{ Follow-up/impact funding } & \\
\hline & & & \multicolumn{3}{|c|}{$\begin{array}{l}\text { Quantitative and qualitative assessment of outputs, outcomes } \\
\text { and pathways to impact }\end{array}$} \\
\hline \multirow{3}{*}{$\begin{array}{l}\text { At the level of FP } \\
\text { components } \\
\text { (clusters, programmes, } \\
\text { societal challenges, } \\
\text { missions, ...) }\end{array}$} & \multirow{3}{*}{$\begin{array}{l}\text { Description of broad } \\
\text { expected impact by } \\
\text { the EC in WPs, or } \\
\text { targets to meet (for } \\
\text { missions) }\end{array}$} & \multicolumn{3}{|l|}{ Clustering } & \\
\hline & & & \multicolumn{3}{|c|}{$\begin{array}{l}\text { Assessment of interaction and communication patterns } \\
\text { between research and societal context at the level of clusters } \\
\text { or programmes }\end{array}$} \\
\hline & & & \multicolumn{3}{|l|}{ Synthesising projects } \\
\hline
\end{tabular}

Fig. 1: A general overview of research impact assessment landscape

Source: LERU (2018) 
If we consider the different approaches and tools available (Table 1), 'theory of change' and the various tools designed for its implementation are widely used. However, most of these tools poorly deal with complexity and uncertainty of research process. Moreover, design thinking may help to stimulate creativity and tools for co-design are well adapted to involve potential users in the innovation process. However, such tools do not take into account explicitly the growing information. Hence, process analyses such as ANT and innovation journey approaches are our best candidates. However, this does not exclude taking advantage of other approaches/tools where relevant.

\begin{tabular}{|c|c|c|c|}
\hline & The impact path & The complexity & The uncertainty \\
\hline $\begin{array}{l}\text { Processual } \\
\text { Impact pathway }++ \\
\text { Complexity }+++ \\
\text { Uncertainty }+++\end{array}$ & $\begin{array}{l}\text { Analysis dividing the process into } \\
\text { sequences } \\
\text { Joint study of the configurations of the } \\
\text { different variables (actors, etc), sequences, } \\
\text { drivers (mechanisms), and bifurcations } \\
\text { (turning points) }\end{array}$ & $\begin{array}{l}\text { In social phenomena, causal relations are } \\
\text { not constant, the results are } \\
\text { unpredictable. } \\
\text { Relational, technological and temporal } \\
\text { complexity }\end{array}$ & $\begin{array}{l}\text { Time is a structuring dimension of the action } \\
\text { that generates lock-in. } \\
\text { Different types of uncertainty. } \\
\text { Control of Innovation: learn to navigate in a } \\
\text { set of possible future }\end{array}$ \\
\hline $\begin{array}{l}\text { Examples of tools that are } \\
\text { affiliated with the approach }\end{array}$ & \multicolumn{3}{|c|}{$\begin{array}{l}\text { FORTH innovation expedition } \\
\text { Constructive Technology Assessment and tools to animate participatory workshops }\end{array}$} \\
\hline $\begin{array}{l}\text { Theory of change } \\
\text { Impact Pathway + } \\
\text { Complexity }++ \\
\text { Uncertainty + }\end{array}$ & $\begin{array}{l}\text { Allows an analysis of the configuration of } \\
\text { the actors and the context } \\
\text { If the nature of the intervention is } \\
\text { predefined: expand the logical steps } \\
\text { towards the objective of the programme } \\
\text { according to a fairly linear approach } \\
\text { (logframe). }\end{array}$ & $\begin{array}{l}\text { Is suitable for complicated: takes into } \\
\text { account the context, past experience, } \\
\text { logical assumptions, between actions } \\
\text { and between production of the results } \\
\text { and achieving the objectives } \\
\text { Requires a consensus of actors on the } \\
\text { general theory to be tested. }\end{array}$ & $\begin{array}{l}\text { Formative dimension of the evaluation: } \\
\text { learning based on experimentation, } \\
\text { coordination of expertise, creation of } \\
\text { relationships and common foundations to } \\
\text { achieve a consensus } \\
\text { Takes into account a finite number of possible } \\
\text { futures. }\end{array}$ \\
\hline $\begin{array}{l}\text { Examples of tools that are } \\
\text { affiliated with the approach }\end{array}$ & \multicolumn{3}{|c|}{$\begin{array}{l}\text { LogFrames; Logical frameworks with inventory of the conditions necessary for the impacts } \\
\text { Participatory Impact Pathway Approach (PIPA); Vianéo Approach }\end{array}$} \\
\hline $\begin{array}{l}\text { Innovative design } \\
\text { Impact pathway } \\
\text { Complexity }+ \\
\text { Uncertainty }+++\end{array}$ & $\begin{array}{l}\text { Design process: define concepts } \mathrm{C} \text { and } \\
\text { knowledge } \mathrm{K} \text { and characterise the operators } \\
\text { necessary for the passage from C-space to K- } \\
\text { space (expansion logic) } \\
\text { Methods that do not explicitly consider the } \\
\text { phases of the impact pathway (e.g. } \\
\text { generalization) }\end{array}$ & $\begin{array}{l}\text { Concepts are tiered to reduce } \\
\text { complexity. } \\
\text { New concepts must stimulate the } \\
\text { production of new knowledge: the } \\
\text { expansion of knowledge and concepts } \\
\text { The identities of objects and their } \\
\text { ecosystems are not fixed. }\end{array}$ & $\begin{array}{l}\text { The unknown is an engine for defining new } \\
\text { design parameters. } \\
\text { The techniques AND functions of the } \\
\text { objects to be conceived are unknown; and } \\
\text { objects and their ecosystems have a } \\
\text { variable identity. }\end{array}$ \\
\hline $\begin{array}{r}\text { Example of tools } \\
\text { affiliated with the approach }\end{array}$ & \multicolumn{3}{|c|}{$\begin{array}{l}\text { Creativity Workshops: TRIZ an Creative Problem Solving on problem solving : STUR method on analysing strategic partnerships ; CCAID } \\
\text { method on the research-action-participation.... : KCP workshops : tools from the IDEAS network }\end{array}$} \\
\hline
\end{tabular}

Table 1: A first overview of approaches and tools available for real time assessment

\section{SKETCHING OUT THE ASIRPA (RT) APPROACH}

\subsection{WHAT DO WE DRAW ON? THE MAIN LESSONS FROM EX POST RIA (ASIRPA PROJECT)}

The lessons learned from ex post RIA play a crucial role in building the real-time approach. The "impact pathway" is the core concept of the ASIRPA approach. We adapted this traditional framework (Douthwaite 2003) and shifted from a quite linear input/output analysis to an approach where:

- the process is divided into phases that are qualitatively different but that do not necessary follow a linear sequence;

- taking our inspiration in ANT, the dynamics are related to translations that allow to create new links between different elements (both human and non-human) and to transform and extend socio-technical associations;
- we do not primarily consider 'inputs' but what we call "productive configurations", a concept that aims at taking into account both the organisational complexity of the research activities considered and their embedding in a wider context;

- we focus on two key elements: (i) the role of intermediaries that play a key role in the dynamics of key translation processes; and (ii) the generalisation or scaling up/out, a phase that is often quite problematic.

The main lessons identified were the following:

- The complexity of the genesis of impacts, generally produced by a set of activities rarely brought together in a single project;

- The importance and diversity of configurations of actors and material resources that produce impacts;

- The identification of critical points along the impact pathway, with a special role of intermediaries and the process of generalization;

- The transformations of the network of actors during the process (an adoption network is generally different from a design network) 


\section{CONTEXT}

(e.g. regulation, socio-economic problems, alternative technologies

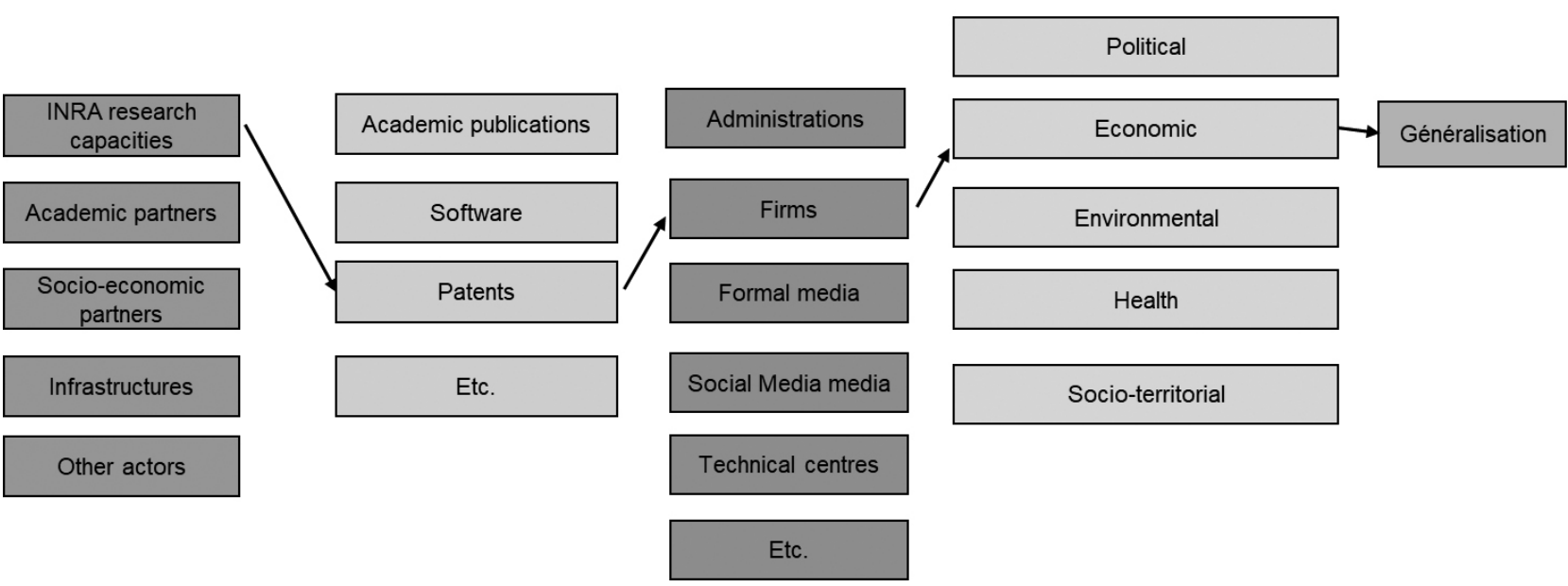

\begin{tabular}{|c|c|c|c|c|}
\hline $\begin{array}{c}\text { INPUTS } \\
\text { (and Productive Configuration) }\end{array}$ & $\begin{array}{c}\text { OUTPUTS } \\
\text { (the products of the research) }\end{array}$ & INTERMEDIARIES & IMPACTS TYPE1 \\
\hline
\end{tabular}

Fig 2: The impact pathway recast in the ASIRPA approach

- The role of the external context which can have facilitating or blocking effects, and open or close, sometimes suddenly, windows of opportunity

- The existence of 4 types of impact paths with different properties and effects:

- The long temporalities of the impact (20 years on average between the initiation of research and the first impacts, with important variations).

\subsection{THE CONCEPTS}

Research and innovation projects are characterized by high levels of complexity and uncertainty. Acknowledging these essential characteristics, the real-time evaluation approach aims to strengthen the capacities of the actors and the dynamics of collective action, thus drawing on two traditions:

- Developmental evaluation (Patton 2016) which informs and guides innovation and development actions that take place in dynamic and complex environments;

- Strategic intelligence (Kuhlman 2003) which aims to strengthen coordination and collective learning.

Moreover, the approach is attentive to the creativity of the actors and to serendipity. While it is necessary for the actors involved to be able to construct a theory of change, i.e. to form an image of the targeted transformations, to represent the impact paths, to identify the critical factors, etc., it is essential that the steering tools allow great flexibility and adaptability. The representation of the process at work is based on the analyses of the innovation journey. Basically, innovation is seen as a sequential, uncertain, complex and singular process. Nevertheless, knowledge of this process helps to identify facilitating and blocking factors. This knowledge must make it possible to design tools to manage the tension between a top-down direction and bottom-up explorations (Mazzucato 2018). The identification of the targeted transformations and the construction of an ex ante impact path must feed into explorations that may have many sources of surprise and that can lead to revising the targets (what Robinson 2009 has described as a reflexive strategy articulation support system). These tools should enable collective learning to be monitored; lessons (and data) from experiments should be collected and analysed.

\subsection{THE PROPOSED APPROACH}

The real-time evaluation process is based on an iterative model whose main lines can be outlined as follows.

\section{TARGET IDENTIFICATION}

What are the anticipated transformations that justify commitment to research? What are the different issues involved in these transformations? What is the magnitude of these transformations in the 5 dimensions of impact?Who are the potential users? How will they be interested in/affected by the transformations?

It should be noted that, given the uncertainties inherent in research, this target often constitutes what may be called a "rational myth": an objective in which we must believe but which we know from the outset is likely to change to a greater or lesser extent. 


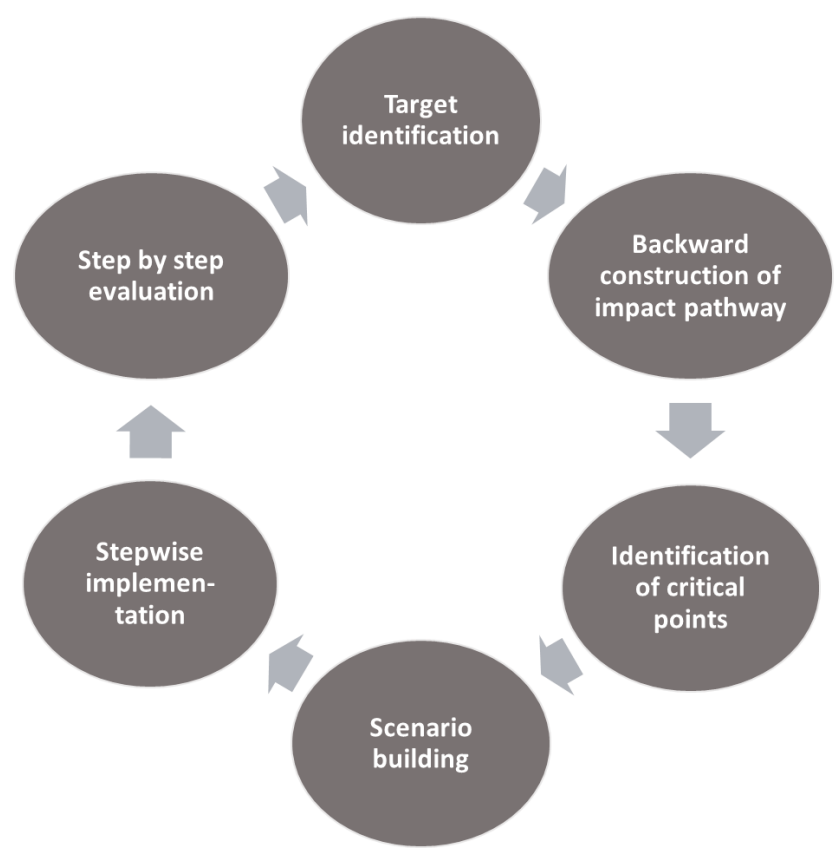

Fig 3: A first representation of the proposed approach

\section{CONSTRUCTION OF THE IMPACT PATHWAY BY BACKWARD INDUCTION}

Who are the key actors and mechanisms involved in the mainstreaming process? What are the blocking and facilitating factors?

Which intermediaries (organisations, technical objects, devices) will enable implementation by the first users?

Who are the knowledge-producing actors? what are the adjacent projects (ongoing, completed, in gestation), by whom are they carried out? what are the complementarities and competition between these projects?

\section{IDENTIFICATION OF CRITICAL POINTS}

What are the critical points associated with the different stages of the impact path? On whom do they depend?

What are the influences of these critical points on the envisaged process?

\section{SCENARIO CONSTRUCTION (SCRIPTS - STEPS, BI- FURCATION)}

Taking into account the main elements above, construct the main scenarios of the project (or group of projects), with the main stages, critical points, bifurcations.

From this, deduce the main meeting points and the anticipated follow-up elements.

\section{STEP BY STEP DECISION AND IMPLEMENTATION}

\section{EVALUATION AT EACH STEP AND NEW LOOP}

This iterative model is constructed and used by the project manager or program manager, often supported by project engineering specialists. It is usually the result of a collective design, with the teams involved and, as necessary, with external partners and potential users. These interactions are based on tools accessible on an online platform.

Essential point: this is a sequential approach. The aim is not to resolve all the questions from the outset but to conduct a process in which the main stages, qualitatively different, are analysed and scattered by internal or external information gains from the project.

The principle is to identify the elements necessary to improve research contribution in the present sequence, bearing in mind the uncertainty about the future. This distinguishes this approach from traditional applications of theories of change. The sequential approach takes seriously the uncertainty, the gain of information during the process (on the state of the art, on the environment, because of relational learning, etc.) and the need to privilege flexibility and adaptability.

At each stage, we seek to optimize the approach by taking into account uncertainty and flexibility. For example, regarding the application of genomic selection methods to the estimation of the genetic value of bulls in milk cattle, proof of concept will be sought before making irreversible development investments; this requires developing a productive configuration to combine quantitative genetics, sample collection and high throughput sequencing skills. The proof of concept being done, we can enrol actors from the sectors who will be involved in the co-development of standardized techniques. For each project, it is therefore necessary to set a transformation objective and to determine the sequence of the main stages qualitatively different. This results in the determination of control points, which leads to the construction of project monitoring dashboards that are very different from the performance indicators generally used in change theory applications. 


\section{IMPLEMENTATION}

ASIRPA't uses a co-design strategy. We have formed a group of $\mathrm{c}$. 15 experts who represent potential users, with strong experience in the coordination of big research projects (e.g. European H2020 projects) or coordination of research programmes of clusters of activities. This working group will be involved in the following process:

1. Workshop 1: User representatives are invited to share their experience (skills, possible tools...) in real time and express their needs;

2. Creation of the prototypes of tools;

3. Workshop 2: the prototype is proposed to the participants, the tools are selected, adapted or, collectively designed;

4. The methodology and its tools are tested by participants on pilot cases supervised by the ASIRPA team;

5. Workshop 3: Feed backs on first use, collective learning

After this first pilot phase, tools will be further developed and their use will be generalised.

\section{CONCLUSION}

Such an intervention research project is a major opportunity to both develop new knowledge on process approaches of research and innovation activities and contribute to key transformations along the ambition to address major challenges.

In the current context, where research impact is a major stake, this project runs the risk to strengthen managerial practices that cherish short-term efficiency, probably at the price of long-term inventiveness. A key challenge of the project is to find ways to articulate directionality and creativity, to favour a good balance between exploration and exploitation. Our choice is to interact strongly with actors who are directly confronted with research coordination issues, in order to strengthen their skills and competences with the hope that we will succeed in transforming, or at least managing, the contradiction between directionality and serenpidity.

\section{REFERENCES}

Bamberger, M., Tarsilla, M. and Hesse-Biber, S. (2016). Why so many 'rigorous' evaluations fail to identify unintended consequences of development programs: How mixed methods can contribute, Eval. Program Plann., 55, 155-162

Bjögvinsson, E., Ehn, P. and Hillgren, P.-A. (2012). Design things and design thinking: Contemporary participatory design challenges. Design Issues, 28(3), 101-116.

Callon, M. (1986). The sociology of an actor-network. Mapping the Dynamics of Science and Technology, Macmillan. M. Callon, J. Law, and A. Rip: London.

Chen, H.T. (1990). Theory-Driven Evaluations. Newbury Park CA: Sage Publications, Inc
Chen, H.T. (2012). Theory-driven evaluation: Conceptual framework, application and advancement. In R.Strobl, 0. Lobermeier and W. Heitmeyer (Eds.), Evaluation von Programmen und Projekten für einedemokratische Kultur (pp. 17-40): Springer.

Cohendet P. and Llerena, P. (1989). Flexilibité, information et décision, Economica, Paris 1989.

Costello, G. J. (2015). Review of innovation process frameworks: Working Paper, Galway: Galway-Mayo Institute of Technology Repository.

Courtney H., Kirkland J. and Viguerie P. (1997). Strategy under uncertainty, Harvard Business Review, 75(6): 66-82.

Douthwaite, B., Alvarez, S., Cook, S., Davies, R., George, P., Howell, J., Mackay, R. and Rubiano, J. (2007). Participatory impact pathways analysis: a practical application of program theory in research-for-development. The Canadian Journal of Program Evaluation 22, 127.

Douthwaite, B., Kuby, T., van de Fliert, E. and Schulz, S. (2003). Impact pathway evaluation: an approach for achieving and attributing impact in complex systems. Agricultural Systems 78, 243-265. doi:10.1016/ S0308-521X(03)00128-8

Ely, A. and Oxley, N. (2014). STEPS Centre research: our approach to impact.

Garud, R, Tuertscher, P. and Van de Ven, A (2013). Perspectives on Innovation Processes. The Academy of Management Annals Vol. 7, No. 1, 773-817, http://dx.doi.org/10.1080/19416520.2013.791066

Hatchuel, A. (2000). Intervention research and the production of knowledge. Cow up a Tree. Knowing and Learning for Change in Agriculture. Case studies from Industrialised Countries 55-68.

Joly, P. B., Matt, M., Gaunand, A., Colinet, L., Larédo, P. and Lemarié, S. (2015). ASIRPA : a comprehensive theory-based approach to assess societal impacts of a research organization, Research Evaluation, 24 (4), 440-453, doi:10.1093/reseval/rvv015.

Joly, P. B. and Matt, M. (2017). Toward a new generation of research impact assessment approaches, Journal of Technology Transfer, DOI 10.1007/s10961-017-9601-0

Jeuffroy M-H and Prost L. (2015). Centre de ressources sur la conception dans les domaines de l'agriculture, de l'environnement et de I'alimentation: intérêt et conditions de faisabilité. Rapport du groupe de travail.

Klerkx, L. and Aarts, N. (2013). The Interaction of Multiple Champions in Orchestrating Innovation Netwokrs: Conflicts and Complementarities, Technovation, 33, 193-210.

Kuhlmann, S. (2003). Evaluation as a source of 'strategic intelligence', in: Learning from Science and Technology Policy Evaluation: Experiences from the United States and Europe. Shapira, P., Kuhlmann, S, pp. 352-379. 
Lorino, P. (1989). L'Economiste et le Manageur, Eléments de Microéconomie pour une nouvelle Gestion, Editions La Découverte, Paris.

Le Masson, P., Weil, B., et Hatchuel, A. (2006), Les processus d'innovation: conception innovante et croissance des entreprises, Stratégie et management (Hermes science.), Paris: Lavoisier.

Matt, M., Gaunand, A., Joly, P.-B., Colinet, L. (2017). Opening the black box of impact - Ideal-type impact pathways in a public agricultural research organization. Research Policy 46, 207-218. doi:10.1016/j. respol.2016.09.016

Mazzucato, M. (2018). Mission-Oriented Research \& Innovation in the European Union: A problem-solving approach to fuel innovation-led growth European Commission. ISBN 978-92-79-79918-1 doi:10.2777/36546

Meynard J.M. et al. (2016). Designing coupled innovations for the sustainability transition of agrifood systems? Agricultural Systems, http:// dx.doi.org/10.1016/j.agsy.2016.08.002

Patton M. 0. (2016). Developmental Evaluation: Applying Complexity Concepts to Enhance Innovation and use, The Guilford Press, New York, London.

Patton, M. 0. (2011). Developmental evaluation: Applying complexity concepts to enhance innovation and use. Guilford Press.

Pawson R (2013) The Science of Evaluation: A Realist Manifesto. London: SAGE.

Retolaza, I. (2011). 'Theory of Change: A thinking and action approach to navigate in the complexity of social change processes'. Hivos/UNDP/ Democratic Dialogue.

Rip, A. (2012). The context of innovation journeys. Creativity and innovation management 21, 158-170.

Rip, A., Schot, J.W. (2002). Identifying loci for influencing the dynamics of technological development.

Robinson, D. (2008). Complexity scenarios for emerging techno-science: adressing strategy-context fit by prospecting level dynamics of governance. Third International seminar on Future-Oriented Technology AnaIysis, Seville, 16-17 October 2008.

Robinson, D. K. R. (2009). Co-evolutionary scenarios: An application to prospecting futures of the responsible development of nanotechnology. Technological Forecasting and Social Change, 76(9), 1222-1239.

Robinson, D. K. R., and Rip, A. (2013). Indications of Socio-Economic Impacts of Nanotechnologies: The Approach of Impact Pathways. In: Konrad, K., Van Lente, H, Coenen, C., Dijkstra, A. and Milburn, C. (Eds.): Shaping Emerging Technologies: Governance, Innovation, Discourse. IOS Press, pp 153 - 166. ISBN 9781614993001.

Rogers, P. (2008). Using programme theory to evaluate complicated and complex aspects of interventions. Evaluation 14, no. 1, 2008: 29-48.
Van de Ven, A, (2016). The innovation journey: you can't control it, but you can learn to maneuver it, Innovation, DOl: $10.1080 / 14479338.2016 .1256780$

Van de Ven, A. H., Polley, D. E., Garud, R., and Venkataraman, S. (1999). The innovation journey, Oxford University Press. ed. New-York.

Van de Ven, A. H., Poole, M. S., (1990). Methods for studying innovation development in the Minnesota Innovation Research Program. Organization science 1, 313-335.

Van de Ven, A. H., Poole, M. S. (1995). Methods for studying innovation development in the Minnesota Innovation Research Program. Longitudinal Fields Research Methods: Studying Process of Organizational Change, GP Huber and AH Van de Ven (Eds) 155-185.

Van Wulfen, G. (2013): The innovation expedition. A visual toolkit to start innovation. Bis Publishers, Amsterdam.

Weiss, C. (1995). Nothing as Practical as Good Theory: Exploring TheoryBased Evaluation for Comprehensive Community Initiatives for Children and Families in 'New Approaches to Evaluating Community Initiatives'. Aspen Institute.

Wigboldus S, with Brouwers J (2016). Using a Theory of Scaling to guide decision making. Towards a structured approach to support responsible scaling of innovations in the context of agrifood systems. Wageningen University and Research, Wageningen.

\section{AUTHORS}

\section{PIERRE-BENOIT JOLY}

LISIS and IFRIS, Université Paris Est

5 Bd Descartes, 77454 Marne-La-Vallée, France

E: joly@inra-ifris .org

\section{MIREILLE MATT, DOUGLAS K. R. ROBINSON}

LISIS and IFRIS, Université Paris Est

5 Bd Descartes, 77454 Marne-La-Vallée, France

E: mireille.matt@inra.f

E: douglas.robinson@esiee.fr 